\title{
Inhibition of Glycosaminoglycan Synthesis Using Rhodamine B in a Mouse Model of Mucopolysaccharidosis Type IIIA
}

\author{
AINSLIE L. K. ROBERTS, BELINDA J. THOMAS, ASHLEY S. WILKINSON, JANICE M. FLETCHER, AND SHARON BYERS
}

Department of Genetic Medicine [A.L.K.R., B.J.T., A.S.W., J.M.F., S.B.], Children, Youth, and Women's Health Service, North. Adelaide, SA 5006 Australia; Department of Paediatrics [A.L.K.R., S.B.], The University of Adelaide, Adelaide, SA 5005, Australia

\begin{abstract}
Reduction of an enzyme activity required for the lysosomal degradation of glycosaminoglycan (gag) chains will result in a mucopolysaccharidosis (MPS) disorder. Substrate deprivation therapy (SDT), a potential therapy option for MPS with residual enzyme activity, aims to reduce the synthesis of gag chains, the natural substrate for the deficient enzyme. Reduced substrate levels would balance the reduced level of enzyme in patient cells, resulting in normalized gag turnover. Rhodamine B, a nonspecific inhibitor, reduced gag synthesis in a range of normal and MPS cells and also decreased lysosomal storage of gag in MPS VI (72\%) and MPS IIIA $(60 \%)$ cells. Body weight gain of male MPS IIIA mice treated with $1 \mathrm{mg} / \mathrm{kg}$ rhodamine B was reduced compared with untreated MPS IIIA mice and was indistinguishable from that of normal mice. Liver size, total gag content, and lysosomal gag was reduced in treated MPS IIIA animals as was urinary gag excretion. Lysosomal gag content in the brain was also reduced by treatment. The alteration in MPS IIIA clinical pathology by rhodamine B, combined with the observation that treatment had no effect on the health of normal animals, demonstrates the potential for SDT in general as a therapy for MPS disorders. (Pediatr Res 60: 309-314, 2006)
\end{abstract}

$\mathrm{T}$ he MPSs are a group of 11 related lysosomal storage disorders that arise from the deficiency of an enzyme activity involved in the intracellular turnover of gag chains (1). The enzyme deficiency results in the accumulation of undegraded gag in a range of cells and leads to pathology that varies according to the MPS type but includes central nervous system (CNS) deterioration, skeletal abnormalities, corneal clouding, and organomegaly (1).

The progressive nature of pathology in MPS presents a continual challenge to the clinical management of patients. Until recently, there has been no multitissue therapy for MPS, with symptoms treated as and when they arise. Bone marrow transplantation (BMT) improves the progression of MPS I and VI $(2,3)$ but has shown variable outcomes for other MPS. Significant morbidity and mortality remain associated with BMT. With the advent of recombinant protein technologies, enzyme replacement therapy (ERT) has been trialed and initiated for several MPSs (4-6). ERT resolves most of the

Received February 17, 2006; accepted May 10, 2006

Correspondence: Sharon Byers, Ph.D., Department of Genetic Medicine, 4th Floor, Rogerson Building, Children, Youth, and Women's Health Service, 72 King William Road, North Adelaide, SA 5006 Australia; e-mail: sharon.byers@adelaide.edu.au

The work described in this paper was supported by grants from The National Health and Medical Research Council of Australia and WCH Research Foundation. A.L.K.R. is the recipient of a University of Adelaide postgraduate scholarship.

DOI: 10.1203/01.pdr.0000233037.00707.da pathology associated with MPS but brain, cartilage, and cornea remain refractory to treatment. In particular, the bloodbrain barrier prevents replacement enzyme from reaching the brain and ERT in its present form is unsuitable for MPS with CNS pathology, i.e. the majority of MPS I, MPS II, and MPS III patients. Direct injection of enzyme into specific sites such as the cisterna magna or the joint space is currently under investigation as a means of targeting brain and cartilage $(7,8)$.

Substrate deprivation therapy (SDT) is an alternative or adjunct therapy option for MPS. The general premise behind SDT is to slow down or prevent the initial accumulation of substrate for the deficient enzyme by inhibiting its synthesis (9). Patients with residual enzyme activity will therefore be able to more effectively turn over substrate. For MPSs, this means reducing the synthesis of one or more of the five different gag chains that accumulate in these disorders (1). Conceptually, gag synthesis inhibitors can affect different points in the gag biosynthetic pathway (10). The nonspecific inhibitor rhodamine B (11) is thought to inhibit chain elongation. The more specific inhibitors of individual gag synthesis, such as 4-deoxy-4-fluoro-2-acetamido-2-deoxy-D-glucose and 4-deoxy-4-fluoro-2-acetamido-2-deoxy-D-galactose, which inhibit heparan sulfate (HS) gag synthesis, also affect chain elongation (12). Alternatively, inhibitors that prevent the addition of sulfate moieties are applicable to MPSs II, IIIA, IIID, IVA, and VI (13). The isoflavone genistein, which inhibits tyrosine kinase, is thought to decrease gag synthesis (14) or the expression of the parent proteoglycan molecule depending on cell type (15). No in vivo studies have been reported for any inhibitor of gag synthesis in MPS disorders.

SDT has been evaluated in two mouse models of non-MPS lysosomal storage disorders: the glycolipid storage disorders Tay-Sachs disease and Sandhoff disease $(16,17)$. Treatment with an inhibitor of glycolipid synthesis, $N$-butyldeoxynorjirimycin (NB-DNJ), prevented the lysosomal accumulation of substrate, slowed the onset of somatic and CNS symptoms, and increased the life expectancy of treated animals. NB-DNJ

Abbreviations: ERT, enzyme replacement therapy; gag, glycosaminoglycan; HS, heparan sulfate; MPS, mucopolysaccharidosis; NB-DNJ, N-butyldeoxynorjirimycin; SDT, substrate deprivation therapy 
is also under clinical evaluation for the treatment of nonneuropathic (type I) Gaucher disease (18). Phase I/II clinical trials clearly revealed a reduction in liver and spleen volume and an increase in hemoglobin and platelet count. Although less effective than ERT, NB-DNJ was approved for treatment of patients with type I Gaucher disease with mild to moderate disease (9). The ease of administration (oral versus i.v. infusion) and the reduced cost of NB-DNJ were considered significant advantages over ERT $(19,20)$. The promising results support the evaluation of the SDT approach in other types of lysosomal storage disorders.

In this study, we report the first SDT treatment for MPS disorders targeting the gag substrate. Rhodamine B, a nonspecific inhibitor of gag synthesis, reduced the lysosomal storage of gag in MPS cells. An in vivo therapy trial set up in the MPS IIIA mouse, which accumulates HS gag, demonstrated that rhodamine B altered several clinical parameters of disease progression toward normal. In particular, a reduction in body weight gain in male MPS IIIA mice and a reduction in liver size, total gag and lysosomal gag content, and urinary gag excretion was observed.

\section{MATERIALS AND METHODS}

Cell isolation. Brain cells were isolated from newborn mice by trypsin digestion (21). The cells were determined to be a mixture of neuronal and glial cells by staining with cell-specific antibodies Neu200 (Sigma Chemical Co.) and GFAP (DAKO), respectively. Normal skin fibroblasts and MPS patient fibroblasts were purchased from the Coriell Cell Repository (Camden, NJ) or obtained from the Department of Genetic Medicine, Children, Youth, and Women's Health Service, after obtaining informed consent. Be(2)-C cells were obtained from ATCC. Skin fibroblasts and primary brain cells were maintained in Dulbecco's modified Eagle's medium supplemented with 10\% fetal calf serum (FCS), $50 \mathrm{U} / \mathrm{mL}$ penicillin $\mathrm{G}$, and $50 \mu \mathrm{g} / \mathrm{mL}$ streptomycin sulfate. $\mathrm{Be}(2)-\mathrm{C}$ cells were maintained in RPMI 1640 medium supplemented as above.

Glycosaminoglycan and protein synthesis. Cells were grown to confluency in six-well plates. For determination of dose response, cells were preincubated with 0 to $100 \mu \mathrm{g} / \mathrm{mL}$ rhodamine $\mathrm{B}$ for $1 \mathrm{~h}$ at $37^{\circ} \mathrm{C}$. Cells were then incubated in the same concentration of rhodamine B plus $5 \mu \mathrm{Ci} / \mathrm{mL}$ $\left.{ }^{35} \mathrm{~S}_{\mathrm{SO}_{4}}\right]$ for $6 \mathrm{~h}$ at $37^{\circ} \mathrm{C}$. The medium was removed, and cells extracted into $4 \mathrm{~mol} / \mathrm{L}$ guanidine $\mathrm{HCl}, 50 \mathrm{mmol} / \mathrm{L}$ sodium acetate $\mathrm{pH} 5.8$ buffer containing $0.1 \mathrm{~mol} / \mathrm{L}$ amino hexanoic acid, $0.05 \mathrm{~mol} / \mathrm{L} \mathrm{Na}_{2}$ ethylenediamine tetraacetic acid (EDTA), and $0.1 \%$ Triton X-100. Unincorporated isotope was removed by size exclusion chromatography on Sephadex G-25 equilibrated in the above buffer. To determine the rate of gag synthesis, cells were preincubated in medium containing $50 \mu \mathrm{g} / \mathrm{mL}$ rhodamine $\mathrm{B}$ for $1 \mathrm{~h}$ at $37^{\circ} \mathrm{C}$, then incubated in the same concentration of rhodamine B plus $5 \mu \mathrm{Ci} / \mathrm{mL}^{35} \mathrm{~S}_{\left[\mathrm{SO}_{4}\right] \text { for up to }}$ $24 \mathrm{~h}$ at $37^{\circ} \mathrm{C}$. The medium and cell layer were treated as above. To measure protein synthesis, cells were preincubated in various concentrations of rhodamine $\mathrm{B}$ as above for $1 \mathrm{~h}$ at $37^{\circ} \mathrm{C}$. Cells were then incubated in the same concentration of rhodamine B plus $5 \mu \mathrm{Ci} / \mathrm{mL}{ }^{3} \mathrm{H}$-serine for $6 \mathrm{~h}$ at $37^{\circ} \mathrm{C}$. Medium was removed and the cell layer scraped into $20 \mathrm{mmol} / \mathrm{L}$ Tris, $0.5 \mathrm{~mol} / \mathrm{L} \mathrm{NaCl}, \mathrm{pH}$ 7.0. Radiolabeled proteins were precipitated with $5 \%$ trichloroacetic acid containing $20 \mathrm{mmol} / \mathrm{L}$ L-serine. The precipitated protein was resuspended in $0.5 \mathrm{~mol} / \mathrm{L} \mathrm{NaOH}$ and radioactivity measured. Synthesis of gag and protein was normalized to cell protein (22).

In vivo administration of rhodamine $B$. The MPS IIIA phenotype is maintained on a mixed genetic background of predominantly $129 \mathrm{SvJ}$ and CD1 with C57B1/6 and SJL contributions (23). MPS IIIA mice were identified by mutation analysis in the week after birth (24). MPS IIIA $(n=5)$ and normal $(n=5)$ mice were injected weekly from 4 wk of age with $1 \mathrm{mg} / \mathrm{kg}$ rhodamine B (in sterile saline) via the tail vein. Body weights were measured weekly and urine was collected every $2 \mathrm{wk}$. Mice were killed at 3, 5, and 7 mo of age (after 2, 4, and 6 mo of treatment). Age-matched untreated MPS IIIA $(n=5)$ and untreated normal $(n=5)$ mice were used as controls. Studies were approved by the Children, Youth, and Women's Health Service Institutional Animal Ethics Committee.
Isolation of urinary gag. Urinary gags were precipitated with two volumes of $0.1 \%$ cetylpyrinium chloride at $37^{\circ} \mathrm{C}$ for $30 \mathrm{~min}$ followed by centrifugation at $1500 \times g$ for $10 \mathrm{~min}$. The pellet was resuspended in $150 \mu \mathrm{L} 2 \mathrm{~mol} / \mathrm{L} \mathrm{LiCl}$ and $0.8 \mathrm{~mL}$ absolute ethanol added to precipitate gags at $-20^{\circ} \mathrm{C}$ for $1 \mathrm{~h}$. The precipitate was recovered by centrifugation at $1500 \times g$ for $10 \mathrm{~min}$, and the pellet resuspended in water. Gag content (25) was normalized to urinary creatinine, measured on a Beckman Synchron CX5 CE autoanalyzer (Synchron CX Systems)

Total tissue gag content. Brain and liver samples were homogenized in five volumes of $6 \mathrm{~mol} / \mathrm{L}$ urea, $0.05 \mathrm{~mol} / \mathrm{L} \mathrm{Na}$ acetate $\mathrm{pH} 5.0,0.1 \%$ Triton $\mathrm{X}-100$ containing protease inhibitors $(0.1 \mathrm{~mol} / \mathrm{L}$ aminocaproic acid, $0.1 \mathrm{~mol} / \mathrm{L}$ $\mathrm{Na}_{2}$ EDTA, $5 \mathrm{mmol} / \mathrm{L}$ benzamidine, $0.5 \mathrm{mmol} / \mathrm{L}$ phenyl methyl sulfonyl fluoride, and $10 \mathrm{mmol} / \mathrm{L} n$-ethylmaleimide) at $4^{\circ} \mathrm{C}$ for $48 \mathrm{~h}$. The tissue homogenate was centrifuged at $7700 \times g$ for $25 \mathrm{~min}$ at $4^{\circ} \mathrm{C}$ and the supernatant applied to DEAE-Sephacel resin equilibrated in $0.1 \mathrm{~mol} / \mathrm{L} \mathrm{Na}$ acetate buffer, $\mathrm{pH}$ 5.0. Columns were washed in 10-column volumes of the same buffer and gags eluted in 5-column volumes of the same buffer containing $2 \mathrm{~mol} / \mathrm{L} \mathrm{NaCl}$. Gag was determined as uronic acid (25) and normalized to tissue weight.

Isolation of lysosomal gags from tissues or cells. Liver or brain tissue was homogenized in five volumes of $0.25 \mathrm{~mol} / \mathrm{L}$ sucrose; $1 \mathrm{mmol} / \mathrm{L}$ EDTA, $\mathrm{pH}$ 7.5; and then loaded on an $18 \%$ Percoll gradient and centrifuged at 32,000 $\times$ $g$ for $60 \mathrm{~min}$ at $4^{\circ} \mathrm{C}(26)$. Aliquots $(1.0 \mathrm{~mL})$ were taken and assayed for $\beta$-hexosaminidase activity (27) to identify the lysosomal fractions. These were pooled and gags purified by DEAE-Sephacel chromatography as above. MPS II, IIIA, VI patient and control skin fibroblasts were grown to confluency $\pm 25 \mu \mathrm{g} / \mathrm{mL}$ rhodamine B for $14 \mathrm{~d}$. On day $14,3 \mu \mathrm{Ci} / \mathrm{mL}^{35} \mathrm{~S}_{\left[\mathrm{SO}_{4}\right]}$ was added to each flask and incubated overnight at $37^{\circ} \mathrm{C}$. Cells were harvested using $0.012 \%$ trypsin, $0.002 \%$ EDTA, homogenized and loaded onto a 30\% Percoll gradient (26), and centrifuged for $60 \mathrm{~min}$ at $32,000 \times g$ at $4^{\circ} \mathrm{C}$. Each gradient was fractionated into $1.0-\mathrm{mL}$ aliquots and processed as above.

Statistical analysis. The relationship between mouse body weight, time, genotype, and treatment was analyzed using restricted or residual maximum likelihood (REML) (28). Tissue weight or gag content versus treatment group was assessed using a one-way analysis of variance with Tukey's honestly significant difference (SPSS, version 11.0).

\section{RESULTS}

Inhibition of gag synthesis by rhodamine $B$ in normal and MPS cells. The addition of increasing concentrations of rhodamine B to the culture medium of MPS IIIA skin fibroblasts or $\mathrm{Be}(2)-\mathrm{C}$ neuroblastoma cells resulted in a dose-dependent decrease in ${ }^{35} \mathrm{~S}\left[\mathrm{SO}_{4}\right]$ incorporation into gags (Fig. $1 a$ and $b$ ). Protein synthesis was unaffected by the addition of rhodamine B up to $75 \mu \mathrm{g} / \mathrm{mL}(p=0.038$, Fig. $1 a)$. The addition of 50 $\mu \mathrm{g} / \mathrm{mL}$ rhodamine $\mathrm{B}$ to cell culture medium resulted in a decrease in gag synthesis in human MPS VI and MPS IIIA skin fibroblasts, normal and MPS IIIA mouse brain cells, and the $\mathrm{Be}(2) \mathrm{C}$ neuroblastoma cell line (Table 1 and Fig. 1c). The inhibition of gag synthesis by rhodamine B led to a reduction of $60 \%$ and $72.5 \%$ in stored gag in the lysosomes of MPS IIIA and MPS VI skin fibroblasts, respectively (Fig. 2).

In vivo treatment with rhodamine $B$ in the MPS IIIA mouse. Both normal and MPS IIIA animals received rhodamine B weekly over a 6-mo treatment period from $4 \mathrm{wk}$ of age. No difference was observed between normal treated and untreated mice with respect to overall physical condition and growth. No difference in body weight gain was observed in either male or female normal mice with treatment (REML, $p=0.5$, data not shown).

Treated MPS IIIA animals lost the scruffy appearance and hunched posture characteristic of the untreated MPS IIIA mice (Fig. 3). All untreated MPS IIIA mice gained weight more rapidly than normal mice such that by 16-wk MPS IIIA males were $129 \%$ of normal and MPS IIIA females were $117 \%$ of normal body weight (Fig. $4 a$ and $b$ ). A decrease in body 

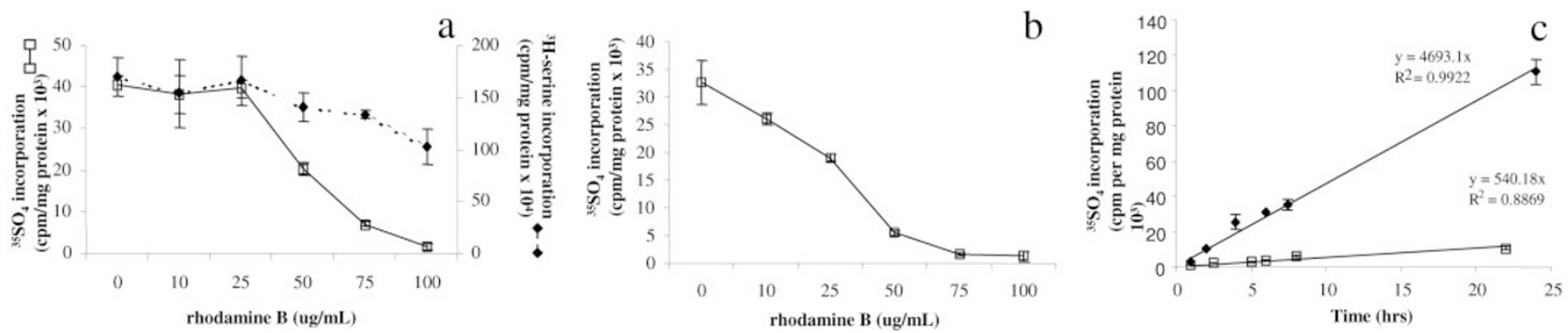

Figure 1. MPS IIIA skin fibroblasts (a) or Be (2)-C neuroblastoma cells $(b)$ were incubated with $0-100 \mu \mathrm{g} / \mathrm{mL}$ rhodamine $\mathrm{B}$ for $6 \mathrm{~h}$ at $37^{\circ} \mathrm{C}$. Be $(2)$ - $\mathrm{C}$ neuroblastoma cells $(c)$ were incubated with $50 \mu \mathrm{g} / \mathrm{mL}$ rhodamine B for various times at $37^{\circ} \mathrm{C} .5 \mu \mathrm{Ci} / \mathrm{mL}^{35} \mathrm{SO}_{4}$ was added to the culture medium to determine gag synthesis or $5 \mu \mathrm{Ci} / \mathrm{mL}^{3} \mathrm{H}$-serine to determine protein synthesis. Results are the mean $\pm \mathrm{SD}$ of three replicates.

Table 1. Inhibition of gag synthesis by rhodamine $B$

\begin{tabular}{clcc}
\hline & & \multicolumn{2}{c}{${ }^{35} \mathrm{SO}_{4}$ incorporation into gag (cpm/ $\mu \mathrm{g}$ cell protein) } \\
\cline { 3 - 3 } Cell type & Phenotype & $0 \mu \mathrm{g} / \mathrm{mL}$ rho B & $50 \mu \mathrm{g} / \mathrm{mL} \mathrm{rho} \mathrm{B}$ \\
\hline Mouse neuronal cells & Normal & $23.0 \pm 3.40$ & $10.54 \pm 1.55(46 \%)$ \\
Human Be(2)C & Neuroblastoma & $26.0 \pm 3.33$ & $2.1 \pm 0.52(8 \%)$ \\
Human skin fibroblasts & Normal & $32.5 \pm 3.27$ & $5.50 \pm 0.32(17 \%)$ \\
& MPS IIIA & $16.81 \pm 1.35$ & $1.89 \pm 0.10(28 \%)$ \\
& MPS VI & $4.36 \pm 0.92$ & $2.26 \pm 0.14(59 \%)$ \\
& MPS II & $14.78 \pm 2.69$ & $9.74 \pm 2.24(66 \%)$ \\
\hline
\end{tabular}

Rhodamine B (Rho B) was added to the culture medium to a final concentration of $50 \mu \mathrm{g} / \mathrm{mL}$ and the rate of gag synthesis determined by the addition of

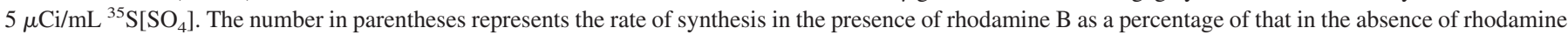
B. Results are expressed as mean \pm standard deviation of three replicates. UD, undetected.

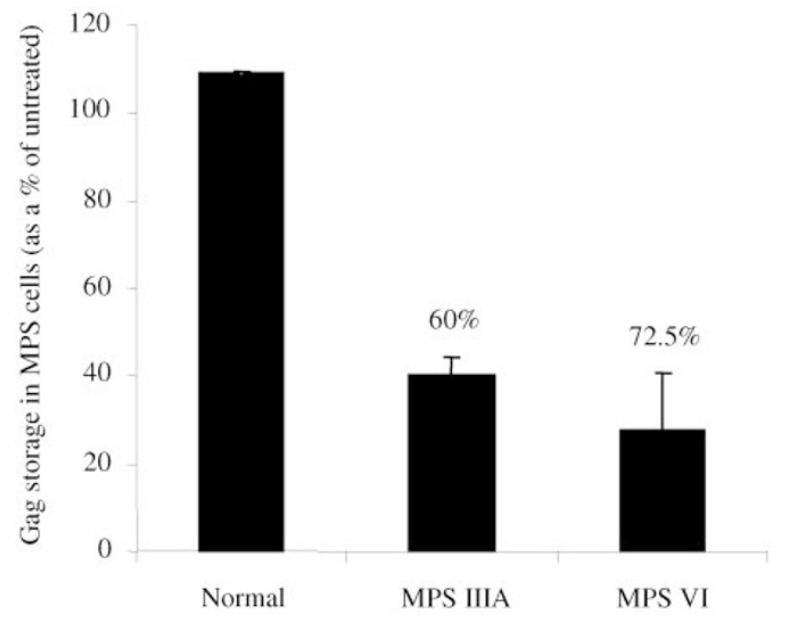

Figure 2. Skin fibroblasts were incubated with $25 \mu \mathrm{g} / \mathrm{mL}$ rhodamine $\mathrm{B}$ for 2 wk before isolation of lysosomes by Percoll gradient centrifugation. Gag was determined as uronic acid and normalized to cell protein. Gag storage in untreated fibroblasts was denoted as $100 \%$ and storage in rhodamine B-treated fibroblasts expressed as a percentage of that in untreated cells. Results are the mean \pm SD of three replicates.

weight gain was observed in treated male MPS IIIA animals compared with untreated littermates that became evident after $100 \mathrm{~d}$ of age (Fig. $4 a$ ), such that at $16 \mathrm{wk}$ of age, treated MPS IIIA animal body weight was $81 \%$ of the untreated MPS IIIA bodyweight and $105 \%$ of normal weight. A reduction in body weight gain by female MPS IIIA mice was also observed on treatment with rhodamine B (to $87 \%$ of the untreated body weight at 16 wk, Fig. $4 b$ ); however, the difference was not significant.

Total urinary gag levels in untreated MPS IIIA mice varied between individual animals but in general was elevated com-

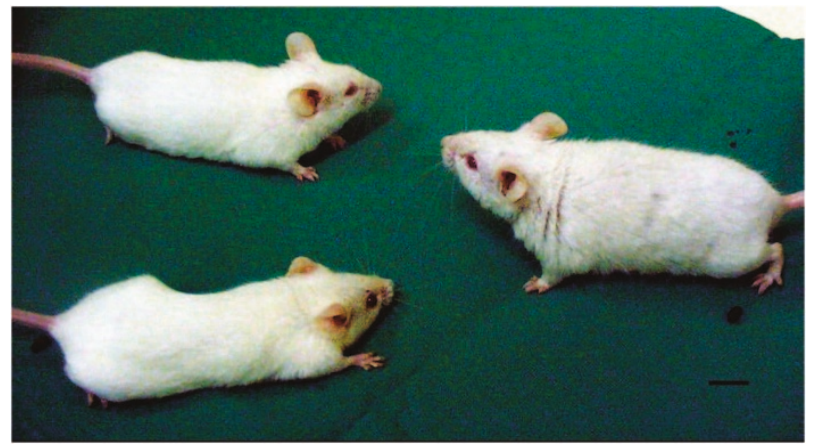

Figure 3. Physical appearance of a MPS IIIA mouse treated with rhodamine B (top left), an untreated MPS IIIA mouse (right), and untreated normal (bottom left) at $7 \mathrm{mo}$ of age. Bar $=1 \mathrm{~cm}$.

pared with normal (Fig. 5). Treatment of MPS IIIA mice with $1 \mathrm{mg} / \mathrm{kg}$ rhodamine B reduced the urinary excretion of gag toward normal. This was particularly evident at earlier times $(<117 \mathrm{~d})$. Treatment of normal animals with $1 \mathrm{mg} / \mathrm{kg}$ rhodamine B had no effect on urinary gag levels (data not shown).

Liver and spleen weight increased with age in MPS IIIA animals (Fig. $6 a$ and data not shown). Treatment with rhodamine B reduced liver weight in MPS IIIA mice but did not affect spleen weight. No alteration in liver or spleen size was observed in the normal animals on treatment $(p>0.05$, data not shown). All other MPS IIIA organ weights fell within the normal range. Total liver gag content was reduced toward normal in MPS IIIA mice treated with rhodamine B (Fig. 6b). No difference was noted in total gag content between untreated and treated liver. The total tissue gag level in other organs was very low, and no change with treatment was observed. After 6 mo of treatment (i.e., at 7 mo of age), 

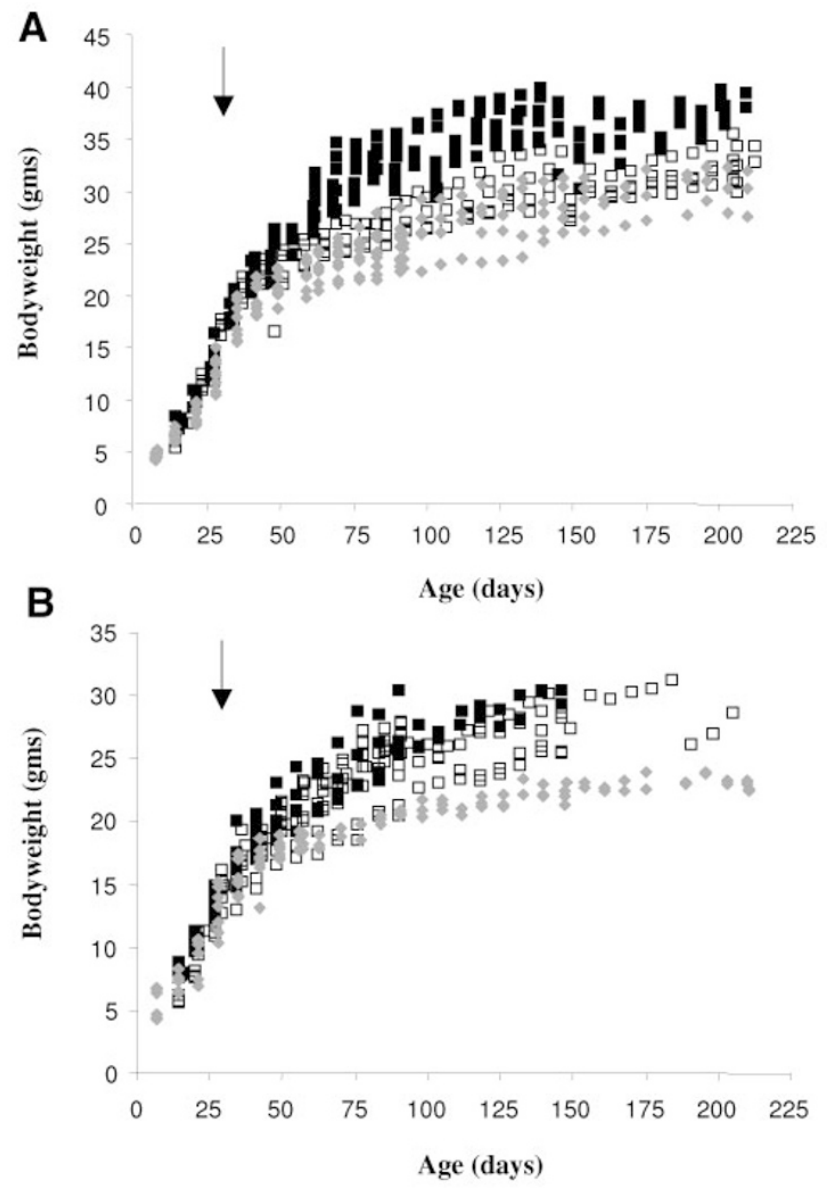

Figure 4. Body weight of male $(a)$ and female $(b)$ normal (shaded diamonds), MPS IIIA untreated (solid squares), and MPS IIIA treated mice (open squares). Arrow denotes when treatment was started. $p<0.001$, REML, untreated MPS IIIA $v s$ normal males. $p=0.0025$, REML, untreated MPS IIIA $v s$ normal females. $p=0.011$, REML, untreated $v s$ treated MPS IIIA males. $p=0.4044$, REML, untreated $v s$ treated MPS IIIA females.

lysosomal gag content in MPS IIIA liver was also reduced toward normal (Fig. 6c). Lysosomal gag content in the brain (the only other tissue examined) also decreased with rhodamine B treatment (Fig. $6 c$ ).

\section{DISCUSSION}

MPS pathology arises from an imbalance between the synthesis and degradation of gag chains. Traditional approaches to correct this imbalance rely on replacing the deficient enzyme to remove accumulated substrate. More recently, novel approaches seek to reduce the synthesis of substrate and thus prevent or minimize its initial accumulation (9). Both methods will result in an overall reduction in the lysosomal burden of gag. Pathology in MPS has been shown to correlate to the level of gag storage (29); thus, any treatment that reduces lysosomal storage is likely to have a positive patient outcome.

In this study, we have shown that rhodamine B reduces gag synthesis in a range of normal and MPS cells including those that display pathology in vivo. In MPS cells, this decrease in gag synthesis led to a reduction in the level of gag within the lysosome. The accumulation of both HS (MPS IIIA fibro-

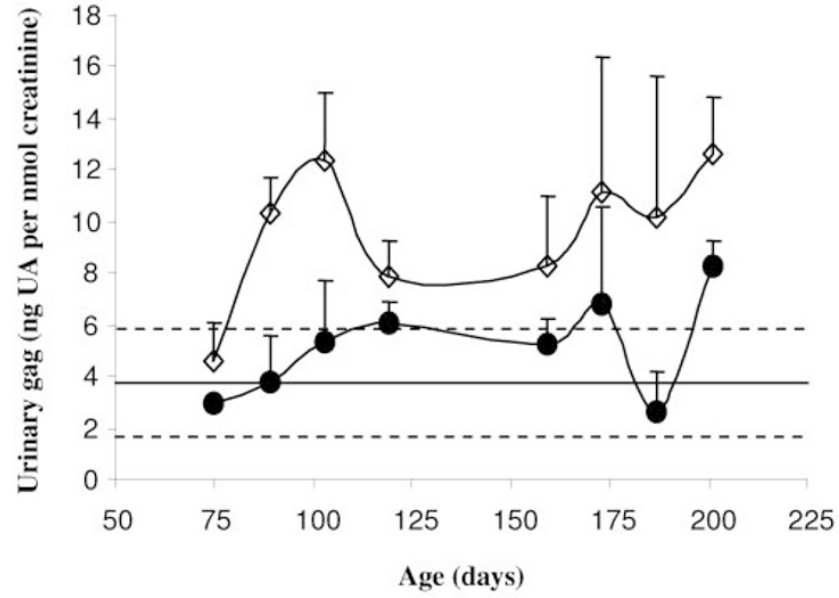

Figure 5. Urinary gag excretion expressed as ng uronic acid/nmol creatinine. MPS IIIA untreated (open diamonds, $n=5$ ) and MPS IIIA treated mice (solid circles, $n=5$ ). The solid and dotted lines represent the average uronic acid concentration in normal urine $\pm 1 \mathrm{SD}$, respectively $(n=5$, mice aged 75-210 d).

blasts) and dermatan sulfate (MPS VI fibroblasts) was reduced by rhodamine B treatment, confirming the general nature of this gag synthesis inhibitor. In MPS patients with detectable residual enzyme activity, the decreased delivery of gag to the lysosome is expected to more closely match remaining enzyme levels and improve the gag turnover rate.

The MPS IIIA mouse is a naturally occurring model of human MPS IIIA with similar biochemical and clinical features $(23,24)$. In vivo, both normal and MPS IIIA mice tolerated the 6-mo treatment regimen with no obvious side effects. No difference was noted in body weight, organ weight, organ gag content, or urinary gag excretion in treated normal mice. This may reflect either the very low level of gag naturally found in normal tissues, which falls at the lower limit of detection of the assay system used or a very rigorous control of gag metabolism. In contrast, treated MPS IIIA mice exhibit a distinct reduction in urinary gag excretion, liver size, total liver gag, lysosomal gag content in liver and brain, and body weight gain compared with untreated MPS IIIA animals.

Compared with normal mice, MPS IIIA mice gain weight faster and have a higher mature body weight (Fig. 4). The increase in abdominal organ weight in affected animals can account for some but not all of the additional bodyweight. HS proteoglycans (HSpgs) are postulated to have a direct effect on adipose tissue by stimulating the uptake of lipid sources such as very low density lipoprotein (VLDL) (30) by either (i) binding and directly internalizing apolipoprotein E-enriched VLDL (31) or (ii) liberating fatty acids for uptake by other transport proteins through the binding of lipoprotein lipase (32). However, no gross change in body fat was noted postmortem in any of the untreated MPS IIIA mice compared with normal or treated MPS IIIA mice (unpublished observation), indicating the excess of HS in MPS IIIA had no direct effect on lipid accumulation and fat deposition. HSpgs have also been implicated in the control of feeding behavior (33). Overexpression of syndecan-1 results in abnormal expression of this HSpg in the hypothalamic nuclei that control energy 

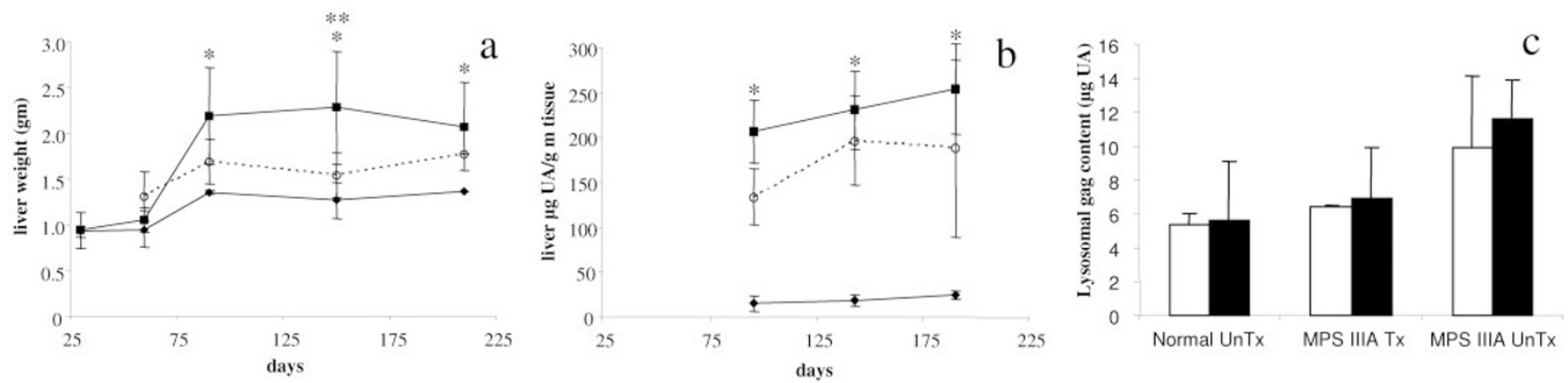

Figure 6. Liver weight $(a)$ and total liver gag $(b)$ content in normal (solid diamonds), MPS IIIA untreated (solid squares), and MPS IIIA treated (open circles) mice $(n=5$ per group). Lysosomal gag content $(c)$ in liver (solid squares) and brain (open squares) of 7-mo-old mice $(n=3)$. * $p<0.05$, Tukey's honestly significant difference, MPS IIIA $v s$ normal. $* * p<0.05$, Tukey's honestly significant difference, untreated $v s$ treated MPS IIIA.

balance and transgenic syndecan-1 mice develop maturityonset obesity. In contrast, mice engineered to overexpress heparanase, one of the enzymes required for HS digestion, displayed reduced food consumption and decreased body weight $(34,35)$. Thus, HS levels in the hypothalamus are intimately involved in the signals that regulate feeding behavior and maintain energy balance and the observation that rhodamine B treatment reduced weight gain in MPS IIIA mice may be an indication that this molecule can affect this control mechanism.

Rhodamine B treatment decreased lysosomal gag content in both the liver and brain of MPS IIIA mice. The latter observation is encouraging and suggests that rhodamine B may have entered the brain. Additional studies are underway to test this directly by measuring neurologic function to assess whether the positive effect of rhodamine B on somatic pathology extends to the CNS. Rhodamine B has a molecular weight of $479 \mathrm{Da}$ and forms a limited number of hydrogen bonds with water; therefore, it possesses the necessary properties for passage across the blood-brain barrier (36).

SDT has the potential to be used in MPS conditions as a stand-alone therapy such as currently used in nonneuronopathic forms of Gaucher disease (18). However, its potential may be more fully realized when considered as an adjunct to other forms of therapy. The efficacy of SDT combined with BMT has been demonstrated in Sandhoff mice (37). Mice on combined therapy survived significantly longer than those on either treatment alone, indicating the potential for combined therapies in patients with a low level of residual enzyme activity. Similarly, combined SDT and ERT can have a number of advantages. Administration of enzyme will have an immediate effect to reduce systemic storage, and continuation of patients on SDT could prevent or slow down reaccumulation of storage. This could have a number of flow-on effects including reducing the dose of enzyme required, frequency of enzyme administration, and altering the mode of administration. Together, these could be expected to lower the financial burden of treatment and increase patient compliance (38). In addition, SDT can be expected to impinge on "difficult to treat" tissues. By nature of their small size, chemical inhibitors can be expected to distribute throughout the body reaching tissues and cells not accessible to large recombinant lysosomal enzymes.
This study demonstrates "proof of concept" that reducing the level of gag synthesis has a positive effect on delaying pathology in an animal model of MPS. To fully understand the potential of SDT as a human therapy capable of addressing all sites of MPS pathology, long-term studies of SDT must be undertaken, preferably in large animal models. Numerous animal models are available encompassing the range of pathology, CNS, skeletal, and otherwise, observed in human MPS (39). The long-term (>6 mo) chronic effect of depressing gag synthesis is unknown but, if present, should become apparent in large animal studies. The choice of SDT agent must also be considered when designing human therapy options. Of the available gag synthesis inhibitors, only rhodamine $\mathrm{B}$ has been tested for toxic effects in vivo. Acute exposure to rhodamine $\mathrm{B}$, at a larger dose than used here, results in mucous membrane and skin irritation in humans (40), whereas the effect of long-term exposure is unknown. Although it may be feasible to use rhodamine B as a SDT agent in vivo, other inhibitors such as the 4-fluoro analogues of naturally occurring sugars described by Berkin et al. (12) may be more practical.

Acknowledgments. The authors thank Kate Dowling, Janine Jones, and Scott Foster, Biometrics SA, for assistance with statistical analysis and Drs. Briony Gliddon and Dyane Auclair for the establishment and initial characterization of the MPS IIIA mice at Children, Youth, and Women's Health Service, Adelaide.

\section{REFERENCES}

1. Neufeld EF, Muenzer J 2001 Mucopolysaccharidoses. In: Scriver CR, Beaudet AL, Sly WS, Valle D (eds) The Metabolic and Molecular Bases of Inherited Disease. McGraw-Hill, New York, pp 3421-3452.

2. Peters C, Shapiro EG, Anderson J, Henslee-Downey PJ, Klemperer MR, Cowan MJ, Saunders EF, deAlarcon PA, Twist C, Nachman JB, Hale GA, Harris RE, Rozans MK, Kurtzberg J, Grayson GH, Williams TE, Lenarsky C, Wagner JE, Krivit W 1998 Hurler syndrome: II. Outcome of HLA-genotypically identical sibling and HLA-haploidentical related donor bone marrow transplantation in fifty-four children. The Storage Disease Collaborative Study Group. Blood 91:2601-2608

3. Krivit W 2002 Stem cell bone marrow transplantation in patients with metabolic storage diseases. Adv Pediatr 49:359-378

4. Harmatz P, Whitley CB, Waber L, Pais R, Steiner R, Plecko B, Kaplan P, Simon J, Butensky E, Hopwood JJ 2004 Enzyme replacement therapy in mucopolysaccharidosis VI (Maroteaux-Lamy syndrome). J Pediatr 144:574-580

5. Wraith JE, Clarke LA, Beck M, Kolodny EH, Pastores GM, Muenzer J, Rapoport DM, Berger KI, Swiedler SJ, Kakkis ED, Braakman T, Chadbourne E, WaltonBowen K, Cox GF 2004 Enzyme replacement therapy for mucopolysaccharidosis I: 
a randomized, double-blinded, placebo-controlled, multinational study of recombinant human alpha-L-iduronidase (laronidase). J Pediatr 144:581-588

6. Muenzer J, Lamsa JC, Garcia A, Dacosta J, Garcia J, Treco DA 2002 Enzyme replacement therapy in mucopolysaccharidosis type II (Hunter syndrome): a preliminary report. Acta Paediatr Suppl 91:98-99

7. Auclair D, Hein LK, Hopwood JJ, Byers S 2006 Intra-articular enzyme administration for joint disease in feline mucopolysaccharidosis VI: enzyme dose and interval. Pediatr Res 59:538-542

8. Kakkis E, McEntee M, Vogler C, Le S, Levy B, Belichenko P, Mobley W, Dickson P, Hanson S, Passage M 2004 Intrathecal enzyme replacement therapy reduces lysosomal storage in the brain and meninges of the canine model of MPS I. Mol Genet Metab 83:163-174

9. Butters TD, Dwek RA, Platt FM 2005 Imino sugar inhibitors for treating the lysosomal glycosphingolipidoses. Glycobiology 15:43R-52R.

10. Prydz K, Dalen KT 2000 Synthesis and sorting of proteoglycans. J Cell Sci 113:193-205

11. Kaji T, Kawashima T, Sakamoto M 1991 Rhodamine B inhibition of glycosaminoglycan production by cultured human lip fibroblasts. Toxicol Appl Pharmacol 111:82-89

12. Berkin A, Szarek WA, Kisilevsky R 2000 Synthesis of 4-deoxy-4-fluoro analogues of 2-acetamido-2-deoxy-D-glucose and 2-acetamido-2-deoxy-D-galactose and their effects on cellular glycosaminoglycan biosynthesis. Carbohydr Res 326:250-263

13. Greve H, Cully Z, Blumberg P, Kresse H 1988 Influence of chlorate on proteoglycan biosynthesis by cultured human fibroblasts. J Biol Chem 263:12886-12892

14. Nikitovic D, Tsatsakis AM, Karamanos NK, Tzanakakis GN 2003 The effects of genistein on the synthesis and distribution of glycosaminoglycans/proteoglycans by two osteosarcoma cell lines depends on tyrosine kinase and the estrogen receptor density. Anticancer Res 23:459-464

15. Schonherr E, Kinsella MG, Wight TN 1997 Genistein selectively inhibits plateletderived growth factor-stimulated versican biosynthesis in monkey arterial smooth muscle cells. Arch Biochem Biophys 339:353-361

16. Platt FM, Neises GR, Reinkensmeier G, Townsend MJ, Perry VH, Proia RL, Winchester B, Dwek RA, Butters TD 1997 Prevention of lysosomal storage in Tay-Sachs mice treated with N-butyldeoxynojirimycin. Science 276:428-431

17. Jeyakumar M, Butters TD, Cortina-Borja M, Hunnam V, Proia RL, Perry VH, Dwek RA, Platt FM 1999 Delayed symptom onset and increased life expectancy in Sandhoff disease mice treated with N-butyldeoxynojirimycin. Proc Natl Acad Sci U S A 96:6388-6393

18. Cox T, Lachmann R, Hollak C, Aerts J, van Weely S, Hrebicek M, Platt F, Butters T, Dwek R, Moyses C, Gow I, Elstein D, Zimran A 2000 Novel oral treatment of Gaucher's disease with N-butyldeoxynojirimycin (OGT 918) to decrease substrate biosynthesis. Lancet 355:1481-1485

19. Moyses C 2003 Substrate reduction therapy: clinical evaluation in type 1 Gaucher disease. Philos Trans R Soc Lond B Biol Sci 358:955-960

20. Zimran A, Elstein D 2003 Gaucher disease and the clinical experience with substrate reduction therapy. Philos Trans R Soc Lond B Biol Sci 358:961-966

21. Jones MZ, Brumfield LK, King BM, Hopwood JJ, Byers S 1998 Recombinant caprine ${ }^{3} \mathrm{H}$-[N-acetylglucosamine-6-sulfatase] and human ${ }^{3} \mathrm{H}$-[N-acetylgalactosamine-4-sulfatase]: plasma clearance, tissue distribution, and cellular uptake in the rat. J Mol Neurosci 11:223-232

22. Bradford MM 1976 A rapid and sensitive method for the quantitation of microgram quantities of protein utilizing the principle of protein-dye binding. Anal Biochem 72:248-254
23. Bhattacharyya R, Gliddon B, Beccari T, Hopwood JJ, Stanley P 2001 A novel missense mutation in lysosomal sulfamidase is the basis of MPS III A in a spontaneous mouse mutant. Glycobiology 11:99-103

24. Gliddon BL, Hopwood JJ 2004 Enzyme-replacement therapy from birth delays the development of behavior and learning problems in mucopolysaccharidosis type IIIA mice. Pediatr Res 56:65-72

25. Blumenkrantz N, Asboe-Hansen G 1973 New method for quantitative determination of uronic acids. Anal Biochem 54:484-489

26. Byers S, Rozaklis T, Brumfield LK, Ranieri E, Hopwood JJ 1998 Glycosaminoglycan accumulation and excretion in the Mucopolysaccharidoses: characterization and basis of a diagnostic test for MPS. Mol Genet Metab 65:282-290

27. Leaback DH, Walker PG 1961 Studies on glucosaminidase. 4. The fluorimetric assay of N-acetyl-beta-glucosaminidase. Biochem J 78:151-156

28. Patterson HD, Thompson R 1971 Recovery of inter-block information when block sizes are unequal. Biometrika 58:545-554

29. Bunge S, Clements PR, Byers S, Kleijer WJ, Brooks DA, Hopwood JJ 1998 Genotype-phenotype correlations in mucopolysaccharidosis type I using enzyme kinetics, immunoquantification and in vitro turnover studies. Biochim Biophys Acta 1407:249-256

30. Wilsie LC, Chanchani S, Navaratna D, Orlando RA 2005 Cell surface heparan sulfate proteoglycans contribute to intracellular lipid accumulation in adipocytes. Lipids Health Dis 4:2-

31. Fuki IV, Kuhn KM, Lomazov IR, Rothman VL, Tuszynski GP, Iozzo RV, Swenson TL, Fisher EA, Williams KJ 1997 The syndecan family of proteoglycans. Novel receptors mediating internalization of atherogenic lipoproteins in vitro. J Clin Invest 100:1611-1622

32. Nielsen MS, Brejning J, Garcia R, Zhang H, Hayden MR, Vilaro S, Gliemann J 1997 Segments in the C-terminal folding domain of lipoprotein lipase important for binding to the low density lipoprotein receptor-related protein and to heparan sulfate proteoglycans. J Biol Chem 272:5821-5827

33. Reizes O, Lincecum J, Wang Z, Goldberger O, Huang L, Kaksonen M, Ahima R, Hinkes MT, Barsh GS, Rauvala H, Bernfield M 2001 Transgenic expression of syndecan- 1 uncovers a physiological control of feeding behavior by syndecan- 3 . Cell 106:105-116

34. Zcharia E, Metzger S, Chajek-Shaul T, Aingorn H, Elkin M, Friedmann Y, Weinstein T, Li JP, Lindahl U, Vlodavsky I 2004 Transgenic expression of mammalian heparanase uncovers physiological functions of heparan sulfate in tissue morphogenesis, vascularization, and feeding behavior. FASEB J 18:252-263

35. Hulett MD, Freeman C, Hamdorf BJ, Baker RT, Harris MJ, Parish CR 1999 Cloning of mammalian heparanase, an important enzyme in tumor invasion and metastasis. Nat Med 5:803-809

36. Pardridge WM 1998 CNS drug design based on principles of blood-brain barrier transport. J Neurochem 70:1781-1792

37. Jeyakumar M, Norflus F, Tifft CJ, Cortina-Borja M, Butters TD, Proia RL, Perry VH, Dwek RA, Platt FM 2001 Enhanced survival in Sandhoff disease mice receiving a combination of substrate deprivation therapy and bone marrow transplantation. Blood 97:327-329

38. Tifft CJ, Proia RL 2000 Stemming the tide: glycosphingolipid synthesis inhibitors as therapy for storage diseases. Glycobiology 10:1249-1258

39. Ellinwood NM, Vite CH, Haskins ME 2004 Gene therapy for lysosomal storage diseases: the lessons and promise of animal models. J Gene Med 6:481-506

40. Dire DJ, Wilkinson JA 1987 Acute exposure to rhodamine B. J Toxicol Clin Toxicol 25:603-607 